\title{
Herd Behaviour \& Investor Sentiment: Evidence from UK mutual funds
}

\begin{abstract}
The aims of this paper are to detect evidence of institutional investor herding behaviour and examine the role that investor sentiment plays in institutional investor herding behaviour. The herding behaviour is investigated by examining the dispersion of time varying beta of UK open-ended and closed-end funds. The study finds evidence of fund manager herding behaviour, which suggests they are likely to herd on market portfolio. UK market-wide investor sentiment index is used for investigating the effects of investor sentiment on institutional herding behaviour. We found a unidirectional investor sentiment effect on the herding of UK mutual fund managers. We also reveal that the sentiment factors affecting UK open-ended and closedend fund managers' herding behaviour are very similar regardless of the differences in fund structure.
\end{abstract}

Keywords: institutional investors; herding; mutual fund; investor sentiment

JEL Classification: G02, G11, G12, G23, 


\section{Introduction}

Our focus on institutional investors seems essential as institutional investors play an everincreasing role as capital suppliers through equity markets, bond markets, and derivative markets (Manconi et. al., 2012). Sias (2004) reveals compelling evidence of the impact of institutional herding behaviour on security prices and market volatility, although institutional investors are often seen as being representative of rational arbitrageurs. Moreover, current research suggests that investor irrational sentiment may have some impact on institutional investors' decision-making, and it may contribute to one of the worst economic crises in modern history in 2007-2008 (e.g. Stelios, et.al. 2017, Olsen, 2011). There is, therefore, strong interest in a better understanding of institutional investor herding and the factors affecting such behaviour. Hence, we aim to re-examine institutional investor herding and its possible causes.

Studies of institutional herding primarily try to find herding evidence at the micro-level by measuring the imbalance in the number of buyers to sellers in one particular stock or group of stocks (e.g. Lakonishok et al., 1992; Wylie, 2005; Claudio \& Schmukler, 2012; Pool at al., 2015). We contribute to the literature by examining institutional herding at the aggregate level, i.e. portfolio return level, where institutional investors mimic a benchmark investment portfolio or market portfolio rather than forming a portfolio according to their own information (Andreu et al, 2015). Particularly, when financial decision-making is influenced by psychological bias, the question of risk attitudes and portfolio choices becomes economically important (Charness \& Gneezy, 2010). We therefore expect to find evidence of herding of institutional investors on portfolio choice through examining their risk attitudes.

A large body of research suggests that investor herding may be a result of an irrational but systematic response to investor sentiment (e.g. Shiller et. al, 1984; Delong et al., 1990; Froot et al., 1992 ; Hirshleifer et al., 1994; Grinblatt et al., 1995; Lux \& Marchesi, 1999; Boco et al., 2010; Friedman, 1984; Dreman, 1979). When sociological, psychological, emotional factors, and fad and fashion play a role in the decision to invest, it is less likely that a rational investment decision will be made. Extensive literature intuitively expects that investor sentiment may be one of the important factors in explaining fund manager herding. Lee et al. (1991), Shleifer (2000), and Barberis and Shleifer (2003) argue that herding might be caused by the same 
irrational moves of individual investors. Blasco et. al (2012) and Economou et. al (2018) suggest that investor sentiment may contribute to investor herding behaviour after examining the relationship between herding proxies and market sentiment indicators ${ }^{1}$. Liao et. al (2011) investigate the role of investor sentiment in fund manager herding. They find that investor sentiment plays a significant role in explaining subsequent mutual fund herding, especially on the sell-side. In this study, we examine the sentiment effects on institutional herding by using a constructed sentiment index, which extracts the sentiment factor from various sentiment proxies.

Our research contributes to the literature in several ways. First, we explore institutional herding from a different angle at an aggregate fund level other than conventional micro individual asset level (Lakonishok et al., 1992; Pool at al., 2015). Second, we extend Huang \& Salmon (2004) approach by using time varying beta estimated via bivariate GARCH to generate a higher frequency institution herding indicator. To our knowledge, this is the first study investigating fund manager herding using weekly frequency, this allows us to look at the herding behaviour in a more detailed (informative) manner. Third, while previous studies focus on investor sentiment being a cause of market herding (Blasco et. al, 2012; Economou et. al, 2018), we found evidence that investor sentiment is also one of the sources of herding behaviour by fund managers. This draws implications to take sentiment of investors into account when framing financial policy on addressing institutional investors' herding actions.

Our estimated results suggest that herding persistently exists among UK open-ended and closed-end mutual funds. This finding is consistent with Lakonishok et al., (1992); Claudio and Schmukler (2012); Pool at al., (2015), etc. We also identify that the herding exists among fund managers despite the differences in the structure and the means of purchase and redemption of fund units. Our study also indicates that investors' sentiment negatively affects UK fund managers' herding behaviour. This suggests that when there is bullish sentiment in the market, fund managers tend to be overconfident and rely on private information leading to less herding, while when there is bearish sentiment in the market, fund managers tend to herd more to avoid

\footnotetext{
${ }^{1}$ Blasco et. al (2012) sentiment indicators are: the put-call trading volume ratio, the put-call open interest ratio, and an index calculated by using volume and number of declining issues traded and the volume and number of advancing issues traded. Economou et. al (2018) use a 'fare' index which is an implied volatility index based on the same methodological approach as the CBOE VIX index. 
punishment if their performance stays at the same level as their peers. This is consistent with Chevalier and Ellison (1999), Menkhoff et. al. (2006), and Boyson (2010).

The rest of the paper is organised as follows: section two reviews the methodology of investigating institutional herding; section three describes the data; section four presents the results of examining the herding evidence, and the investigation of the relationship between herding variables and investor sentiment indices; section five concludes.

\section{Methodology of investigation of Institutional herding}

Examining the level of individual asset returns clustering around the average market return is one of the major methods of investigating herding behaviour. These methods generally use cross-section of return dispersions as the media (Christie \& Huang, 1995; Chang, Cheng and Khorana, 2000). To control movements in fundamentals, Hwang \& Salmon (2004) suggest that if herding exists in the conventional Capital Asset Pricing Model (CAPM), the equilibrium relationship no longer holds, and both the beta and the expected return will be biased. Herding may therefore be detected through examining cross-sectional dispersion of the factorsensitivity, i.e. the beta. Theoretically, institutional herding can be examined in a similar manner. Based on Hwang \& Salmon (2004), the following relationship holds:

$$
\frac{E_{t}^{b}\left(r_{i, t}\right)}{E_{t}\left(r_{m, t}\right)}=\beta_{i, t}^{b}=\beta_{i, t}-h_{t}\left(\beta_{i, t}-1\right)
$$

where $E_{t}^{b}\left(r_{i, t}\right)$ is the biased short run conditional expectation return on the fund $i, \beta_{i, t}^{b}$ is the biased beta of fund $i$ at time $t$ and $E_{t}\left(r_{m, t}\right)$ is the expected market return, $h_{t}$ is a latent herding parameter which captures herd behaviour, and $\beta_{i, t}$ measures the sensitivity of the asset return toward market return.

Equation 1 suggests that perfect herding holds where $h_{t}=1$, meaning that the fund perfectly mimics the market portfolio; where $h_{t}=0$, there is no herding. In general, $h_{t}>0$ implies the expected fund return herds toward the market portfolio return, and $h_{t}<0$ suggests an adverse herding exists (Hwang \& Salmon, 2004). 
When exploring market-wide portfolio herding, equation 1 is assumed to hold for all portfolios and the cross-sectional mean of $\beta_{i, t}^{b}\left(\operatorname{or} \beta_{i, t}\right)$ is always $1^{2}$. Standard deviation of $\beta_{i, t}^{b}$ is:

$$
\begin{gathered}
\operatorname{Std}_{c}\left(\beta_{i, t}^{b}\right)=\sqrt{E_{c}\left(\left(\beta_{i, t}-h_{t}\left(\beta_{i, t}-1\right)-1\right)^{2}\right)}=\left(1-h_{t}\right) \sqrt{E_{c}\left(\left(\beta_{i, t}-1\right)^{2}\right)} \\
=\left(1-h_{t}\right) \times \operatorname{Std}_{c}\left(\beta_{i, t}\right)
\end{gathered}
$$

where $S t d_{c}$ is standard deviation of the cross-section of $\beta_{i, t}^{b}$ or $\beta_{i, t}$, and $E_{c}$ is the crosssectional expectation $\beta_{i, t}^{b}$ or $\beta_{i, t}$.

A state space model will be derived by taking logarithms of equation 2 with a mean zero AR(1) process (Hwang \& Salmon, 2004), and the herding variable, $h_{t}$, is able to be estimated. The investigation is based on the argument that herding may lead to time-varying betas. A bivariate GARCH model may be preferred as the conditional covariance and variance estimated from the model are time-dependent, resulting in the estimators being more likely to be unbiased and efficient (Choudhry, 2005; and Choudhry et al., 2010). Although Hwang \& Salmon (2004) argue that their OLS estimated monthly beta is unbiased, OLS is unsuitable not only for estimating higher frequency betas, e.g weekly and daily, but also suffers from inefficiency if beta is not constant (Black, Fraser and Power, 1992).

We use Engle and Kroner's (1995) BEKK version of bivariate GARCH $(1,1)$ model to estimate the betas. The conditional variance-covariance matrix of the model is specified as follows (Tsui and Yu, 1999; Choudhry et al., 2010 and Yin et al., 2017):

$$
\begin{gathered}
Y_{t}=V+\Xi_{t} \\
\Xi_{t}=K_{t}^{\frac{1}{2}}(\theta) Z_{t} \\
K_{t}=C^{\prime} C+A^{\prime} \Xi_{t-1} \Xi_{t-1}^{\prime} A+B^{\prime} K_{t-1} B
\end{gathered}
$$

\footnotetext{
${ }^{2}$ The cross-sectional expected $\beta_{i, t}$ is the expectation against the overall markets at one point in time, which implies a perfect diversification, therefore the cross-sectional expectation of $\beta_{i, t}$ is 1 , so as $\beta_{i, t}^{b}$. Hwang \& Salmon (2004) examine and proved it.
} 
where $Y_{t}=\left(R_{i t}, R_{m, t}\right)$ is a $2 \times 1$ vector containing continuously compounded returns of the fund $i$ and the market portfolio $m ; V$ is a vector of 2 constants; $K_{t}{ }^{3}$ is a $2 \times 2$ conditional variance-covariance matrix of the residuals $\Xi_{t} ; C, A$ and $B$ are $2 \times 2$ coefficient matrices. The variance-covariance matrix $K_{t}$ is rewritten as:

$$
\begin{aligned}
& {\left[\begin{array}{ll}
k_{11, t} & k_{12, t} \\
k_{21, t} & k_{22, t}
\end{array}\right]=\left[\begin{array}{ll}
c_{11} & c_{12} \\
c_{21} & c_{22}
\end{array}\right]^{\prime}\left[\begin{array}{ll}
c_{11} & c_{12} \\
c_{21} & c_{22}
\end{array}\right]+\left[\begin{array}{ll}
a_{11} & a_{12} \\
a_{21} & a_{22}
\end{array}\right]^{\prime}\left[\begin{array}{cc}
\Xi_{1, t-1}^{2} & \Xi_{1, t-1} \Xi_{2, t-1} \\
\Xi_{2, t-1} \Xi_{1, t-1} & \Xi_{2, t-1}^{2}
\end{array}\right]\left[\begin{array}{ll}
a_{11} & a_{12} \\
a_{21} & a_{22}
\end{array}\right]+} \\
& {\left[\begin{array}{ll}
b_{11} & b_{12} \\
b_{21} & b_{22}
\end{array}\right]^{\prime}\left[\begin{array}{ll}
k_{11, t-1} & k_{12, t-1} \\
k_{21, t-1} & k_{22, t-1}
\end{array}\right]\left[\begin{array}{ll}
b_{11} & b_{12} \\
b_{21} & b_{22}
\end{array}\right]}
\end{aligned}
$$

Then, the time-varying beta of a fund $i, \beta_{i, t}^{b}$, is computed as

$$
\beta_{i, t}^{b}=\frac{\operatorname{cov}\left(r_{i}, r_{m}\right)}{\sigma_{r_{m}}^{2}}=\frac{k_{12, t}}{k_{22, t}}
$$

where $k_{12, t}$ is estimated as the conditional covariance between fund $i$ 's returns and the market portfolio returns and $k_{22, t}$ is the conditional variance of the market portfolio returns. Given that $k_{12, t}$ and $k_{22, t}$ are time-dependent, the estimated beta will be time-dependent.

The beta estimated by Equation 3 is applied in this paper. By computing the standard deviation of the cross-section of $\beta_{i, t}^{b}$, we firstly examine whether institutional investors herd at portfolio level.

H1: Institutional investors herd at the portfolio level.

According to Hwang \& Salmon (2004), taking logarithms of equation 2 with a mean zero AR(1) process, the state space model that is used to estimate the latent herding parameter, $h_{t}$, is as follows:

$$
\log \left[\operatorname{Std}_{c}\left(\beta_{i, t}^{b}\right)\right]=\mu+H_{t}+v_{t}
$$

\footnotetext{
${ }^{3}$ The common notation should be $H_{t}$, however, due to the conflict with herding variable, we use $K_{t}$ instead. 


$$
H_{t}=\phi H_{t-1}+\eta_{t}
$$

where $H_{t}=\log \left(1-h_{t}\right), \log \left[\operatorname{Std}_{c}\left(\beta_{i, t}\right)\right]=\mu+v_{t}, \mu=E\left(\log \left(\operatorname{Std}_{c}\left(\beta_{i, t}\right)\right)\right), v_{t} \sim \operatorname{iid}\left(0, \sigma_{v}^{2}\right)$, and $\eta_{t} \sim i i d\left(0, \sigma_{\eta}^{2}\right)$.

When $\sigma_{\eta}^{2}=0$, the model becomes $\log \left[\operatorname{Std}_{c}\left(\beta_{i, t}^{b}\right)\right]=\mu+v_{t}$, which means no herding exists, indicating $H_{t}=0$ for all $t$. The existence of herding can be captured by a statistically significant value of $\sigma_{\eta}^{2}$ (Hwang \& Salmon, 2004).

Secondly, by including market fundamental and macroeconomic factors, we investigate the causes of herding behaviour.

The model of equation 4 and 5 is moderated to be able to indicate sources of herding behaviour (Hwang \& Salmon, 2004):

$$
\begin{array}{r}
\log \left[\operatorname{Std}_{c}\left(\beta_{i, t}^{b}\right)\right]=\mu+H_{t}+\theta_{1} \log \sigma_{m t}+\theta_{2} R_{m t}+\theta_{3} R_{m t}^{F} \\
+\theta_{4} T S_{t}+\theta_{5} R T B_{t}+v_{t} \\
H_{t}=\phi H_{t-1}+\eta_{t}
\end{array}
$$

Where $\log \sigma_{m t}$ is market volatility, $R_{m t}$ is market return, $R_{m t}^{F}$ is foreign market return, $T S_{t}$ is the term spread, $R T B_{t}$ is the relative Treasury Bill rate at time $t$.

Finally, based on the estimation results from equation 6 and 7, if the herding behaviour is not caused by market fundamental and macroeconomic factors, (i.e. $\sigma_{\eta}^{2}$ is still significant), we are going to identify whether investor sentiment is one of the sources of herding.

H2: Investor sentiment has effect on institutional herding 
The effects of investor sentiment on herding behaviour of fund managers are investigated by directly examining the herding variable against a sentiment index. The sentiment index is constructed by applying Baker and Wurgler (2006) method, which is widely used in literature (for example, Chen, et al, 2010, Baker, et al, 2012, Chen, et al, 2014, Bai, 2014, and Hudson and Green, 2015). In our research, the investor sentiment indicator is UK market-wide sentiment index (SENT) (see Appendix 1 for detailed construction of the index).

Studies, such as Shiller et. al. (1984), Froot et al. (1992), Hwang and Salmon (2017), and Economou et. al (2018), suggest that herd behaviour and sentiment may act as a system. A vector autoregression (VAR) model, therefore, is more likely to be suitable for exploring the directional relation, to see how sentiment and herd behaviour interact, and to identify the (statistical) causality relationship. Market return is also included in the model to control any effects from the market. The general model is

$$
Y_{t}=\Delta+\sum_{j=1}^{p} \Theta_{i} Y_{t-j}+\varepsilon_{t}
$$

where $Y_{t}=h_{t}, R_{m, t}, S E N T_{t}$, and $\Delta$ and $\Theta_{i}$ are matrices of coefficients to be estimated. $h_{t}$ is the level of investor's herding behaviour at time $t$, where $h_{t}=\left(1-\exp \left(H_{t}\right)\right)$, and $H_{t}$ is the estimated variable of the equation 6 and 7; $R_{m}$ is the market return; SENT is the constructed UK market investor sentiment index. Model selection metrics such as SBIC and HQIC suggest $j=2$.

\section{Data Description}

UK mutual funds are selected for the investigation of institutional herding behaviour. The sample period is from 01 January 1996 to 31 December 2015. UK investment funds of Unit Trust and Open-ended investment companies (OEICs) are often classified as income unit (or share) or accumulation unit (or share). Some of the mutual funds hold both Accumulation Unit and Income Unit accounts. In order to avoid duplication, only the Accumulation Unit account is chosen in the sample if the fund has both accounts. We adjust those Income Units for dividend and other investment incomes that have been paid out by cash to keep the prices comparable in different classes of fund. We also filter out funds that have been discontinuous 
or are inactive. 64 UK Unit trusts and OEICs satisfied the criteria and are used as samples to examine open-ended fund managers. 104 London Stock Exchange listing closed-end funds are selected to be used for examination of the herding behaviour of closed-end fund managers ${ }^{4}$.

Fund return is calculated by using daily prices (Net Assets Value) of open-ended (closed-end) funds. FTSE 350 Index is used as market return. S\&P 500 Index represents foreign market returns. The term spread (TS) is the difference between the UK 3-month Treasury Bill rate and the UK 10-year Government Bond rate. The relative Treasury Bill Rate $(R T B)$ is the difference between the UK 3-month Treasury Bill rate and its 4-week moving average. They are collected at a weekly frequency from Datastream databases.

In order to be able to construct sentiment index, series data of sentiment proxies are also collected. The number of stocks rising and the number of stocks falling in the UK market is used to calculate the Advances to Declines ratio (AVDC). The prices and Net Asset Values of Closed-end investment trusts, which are listed on the London Stock Exchange are used in the calculation of the Closed-end Fund Discount (CFED). FTSE 100 index weekly high, low and closing prices are used for calculating the Money Flow Index (MFI) and the Relative Strength Index (RSI). Trading volumes of FTSE100 index put option and call option are used to calculate the Put-call Trading Volume ratio (PCV). FTSE100 index put option and call option open interests are used for calculating the Put-call Open Interest ratio (PCO). FTSE100 index future prices is used for computing the Realized Volatility (VOLA). Trading Volume (VRA) is the FTSE 100 trade volume. The methods of computing the variables follow that of Hudson $\&$ Green $(2015)^{5}$. These variables are used for constructing the sentiment index and they are collected at weekly frequency from Datastream databases.

Table 1 provides summary statistics of the key variables. The natural log of beta standard deviation of open-end funds ( $\left.\log S D_{o p}\right)$ and the nature $\log$ of beta standard deviation of closedend funds $\left(\log S D_{c l}\right)$ are distributed in a similar manner. Both of them skew to the left and the standard deviations are 0.87 . They may both have first order autocorrelation but the ADF tests show they are stable series. $\log S D_{o p}$ has Kurtosis of 4.887 indicating a heavy-tailed distribution. $\log S D_{c l}$ has Kurtosis of 2.73 suggesting it is also heavy-tailed but lighter than that

\footnotetext{
${ }^{4}$ Sample funds satisfy the condition of existing and being alive during the overall sample period.

${ }^{5}$ They are briefed in Appendix 1.
} 
of $\log S D_{o p}$. The open-ended fund herding variable, $h_{o p}$, and closed-end fund herding variable, $h_{c l}$, both have negative means with standard deviation of approximate 0.4 . They both skew right. The autocorrelation tests indicate $h_{o p}$ and $h_{c l}$ may have first order autocorrelation, the ADF tests show they are stable series. The market-wide sentiment index, SENT, has a negative mean (-0.0007) and skews left, which may indicate that the market-wide sentiment during the sample period is generally low. The autocorrelation test suggests that SENT may be highly autocorrelated, however, the test shows that the timeseries is still stable.

[Inset table 1 about here]

\section{Results}

The estimations of open-ended funds (Table 2) indicate that herding is highly persistent in the market. The estimated $\sigma_{\eta}^{2}$ is statistically significant at $1 \%$ level, suggesting that the standard deviation of $\eta_{t}$ is highly possibly not zero, implying $H_{t} \neq 0$. The significant $\phi$ also supports the particular autoregressive structure. $|\phi| \leq 1$ satisfies the requirement that herding toward the market portfolio is not an 'explosive' process, hence $H_{t}$ is stationary. Therefore, the hypothesis of institutional investor herd at portfolio level is confirmed.

[Inset table 2 about here]

The examination of whether the herd behaviour is caused by market fundamental and macroeconomic factors indicates that they are unlikely to generate much institutional investor herding behaviour. The significant $\sigma_{\eta}^{2}$ and $\phi$ in Table 2 Model 2 suggests that the investor herding behaviour exists after considering market fundamental and macroeconomic factors. The estimated results provide evidence that the herding behaviour may not solely be caused by market fundamental and macroeconomic factors: it suggests that herding behaviour of UK fund managers may also be driven by other factors such as investor sentiment.

The results from UK closed-end funds are very similar to those of open-ended funds (Table 2), although they are in a different form of structure and have very different investment focuses. This implies that herding behaviour is a general practice amongst fund managers. Our results are consistent with other empirical research, indicating that individual manager's investment 
behaviour is affected by his/her peer groups, and herding behaviour increases over time (Graham, 1999; Li, 2002; Bertrand and Schoar, 2003; Boyson, 2010).

This study is particularly interested in investigating whether irrational investor sentiment could cause institutional herding. In order to examine the causal relationship between investor sentiment and institutional herding, a more direct approach is undertaken, i.e. finding the directional relationship by estimating a VAR model (Equation 8).

Table 3 shows the VAR results among variable of $h_{c l}, h_{o p}, S E N T, R_{m}$. For both $h_{o p}$ and $h_{c l}$, the first two lagged of SENT are statistically significant, indicating that SENT have some explanation powers over the fund herding indicators. Combining with Granger Causality test in Panel B, it suggests a 'one-way' direction, meaning SENT significantly causes both openedend and closed-end fund herding. In addition, the negative correlations of UK market-wide investor sentiment on UK mutual fund herding suggest that increase (decrease) in investor sentiment would decrease (increase) the level of fund herding. Our findings are also consistent with Chevalier and Ellison (1999) and Boyson (2010), showing that fund managers who are confident about their performance are more likely to deviate from the herd.

[Inset table 3 about here]

The impulse response functions of VAR trace out the responsiveness of the dependent variables in the VAR to shocks to the error term. Figure 1 displays how herding responds to a positive sentiment shock. Figure 1 (a) and (b) show how both funds' herding reacts to market-wide sentiment shock. After the shock, herding changes to the negative direction, suggesting that the higher the investor sentiment, the lower the degree of herding behaviour. Market-wide sentiment reflects the sentiment of overall market participants including individual investors and institutional investors. Psychological bias of overconfidence may be a major factor of the sentiment, which means that investors tend to overweight their private information and be too certain of their ability to predict future performance of assets (Baker \& Nofsinger, 2002; Caballe \& Sakovice, 2003; Odean, 1998). The more overconfidence, the heavier the weight investors put on their private information and the more certain they are about their opinions. This is more likely to derive diverse decisions and therefore have a negative effect on herding behaviour. 
From Figure 1, it is clear that the shock from investor sentiment lasts for a relatively longer period for open-ended fund herding as compared to that of closed-end fund. Market-wide sentiment represents all market participants (including individual investors and institutional investors). The un-unified actions from individual investors may lead to the longer period responses. This is due to being highly influenced by individual investors on open-ended funds through unrestricted redemption. This may imply that open-ended fund managers are likely to be influenced by a relatively wider range of investors' sentiment compared to that of closedend funds.

[Inset figure 1 about here]

\section{Conclusion}

One of the main objectives of our paper is to investigate whether institutional investors herd on their investment decision-making. We extend Huang \& Salmon's (2004) method by using bivariate GARCH method estimated time varying beta to examine the UK open-ended and closed-end fund managers' herding behaviour. We have found some evidence of herding behaviour among the fund managers, both open-ended funds and closed-end funds. Further investigations suggest that market fundamentals and macroeconomic factors might not be the only sources of the UK fund managers herding behaviour. Investor sentiment may be also one of the sources contributing to fund managers' herding behaviour.

Another main objective of our paper is to examine whether investor sentiment has some effect on fund managers' herding behaviour. This has been conducted by utilising the constructed UK market-wide sentiment index. The relationship between institutional herding and investor sentiment has been investigated by applying the VAR method. The results suggest that UK market-wide sentiment has some effect on herding of UK fund managers, both open-ended and closed-end. These effects are unidirectional, indicating investor sentiment may be one of the sources of UK fund managers herding.

The study also reveals that the sentiment factors affecting UK open-ended and closed-end fund managers' herding behaviour are very similar regardless of whether the structure and investment portfolios are significantly different. UK fund managers' herding behaviour is negatively affected by investors' sentiment. This may indicate that sentiment factors affect 
herding behaviour through psychological bias such as overconfidence. Our paper, moreover, reveals that open-ended fund managers are likely to be influenced by a relatively wider range of investors' sentiment than that of closed-end funds. This may be because the structure and investment portfolios of open-ended funds are significantly different from closed-end funds.

Our research results may have some implications on comprehensive policies for regulators of the financial industries. We have found evidence that investor sentiment may contribute to institutional investor herding behaviour. The irrational herding behaviour of institutional investors may increase financial market volatility, or in some extreme cases, cause bubbles and crashes. Market regulators could implement a mechanism that is able to systematically monitor investor sentiment and predict institutional investors' herding behaviour, hence, to set up policies, which can help to stabilise financial markets. 


\section{Table 1: Statistics Summary of Data for investigating mutual funds herding}

Table 1 provides summary statistics of the basic data series. The data are weekly and cover the period $1^{\text {st }}$ January 1996 to $31^{\text {st }}$ December 2015.

\section{Variable definitions:}

$\boldsymbol{R}_{m}$ : is the market return which is calculated from FTSE 350 Price Index; $\boldsymbol{R}_{m}^{F}$ : the foreign market return which is calculated by use S\&P 500 Price Index. LogSD $o p$ is nature log of beta standard deviation of open-end funds. LogSD $c l$ is nature log of beta standard deviation of closed-end funds. TS: the Term Spread defined as the difference between the rate on UK 10 year gilt and UK 3 month Treasury bill. TSD the first difference of TS. RTB, the relative treasury bill rate, is defined as the difference between the UK 3 month treasury bill rate and its 12 -month moving average. Volt: Market volatility; SENT is UK market investor sentiment index; $\boldsymbol{h}_{o p}$ is the herding measure generated by Hwang and Salmon (2004) approach from UK open-ended funds; $\boldsymbol{h}_{\boldsymbol{c}}$ is the herding measure generated by Hwang and Salmon (2004) approach from UK closed-end funds. AC (1) is autocorrelation coefficient at one lag. ADF is Augmented Dickey-Fuller test statistic with maximum 52 lags. Obs is number of observation.

* Statistical significance at $1 \%$ level; **Statistical significance at $5 \%$ level; *Statistical significance at $10 \%$ level.

\begin{tabular}{|c|c|c|c|c|c|c|c|c|c|c|}
\hline Variable & Mean & Std. Dev. & Skewness & Kurtosis & Jarque-Bera & Sum Sq. Dev. & $\mathrm{AC}(1)$ & $\mathrm{AC}(2)$ & ADF & Obs \\
\hline $\boldsymbol{R}_{m}$ & 0.04569 & 2.0511 & -0.5972 & 6.0041 & $454.1832^{* * *}$ & 4383.557 & -0.056 & -0.003 & $-34.12^{* * *}$ & 1043 \\
\hline $\boldsymbol{R}_{m}^{F}$ & 0.0937 & 2.1369 & -0.1383 & 8.8577 & $1494.480^{* * *}$ & 4758.24 & -0.077 & 0.032 & $-34.8863^{* * *}$ & 1043 \\
\hline $\operatorname{LogSD}_{o p}$ & 2.4079 & 0.8747 & -2.132 & 4.887 & $1809.393^{* * *}$ & 2513.52 & 0.509 & 0.297 & $-18.4157^{* * *}$ & 1043 \\
\hline $\operatorname{LogSD}_{c l}$ & 1.8793 & 0.8674 & -1.575 & 2.073 & $608.258^{* * *}$ & 785.44 & 0.462 & $0 . .257$ & $-19.5835^{* * *}$ & 1043 \\
\hline TS & -0.8617 & 1.3247 & -0.1741 & 2.1136 & $39.4126^{* * *}$ & 1828.77 & 0.995 & 0.991 & -1.3791 & 1043 \\
\hline TSD & 0.0003 & 0.1292 & 0.8845 & 9.7241 & $2098.90 * * *$ & 17.3875 & -0.104 & 0.026 & $-35.8024 * * *$ & 1042 \\
\hline RTB & -0.0084 & 0.0787 & -4.6041 & 45.6005 & $82553.35^{* * *}$ & 6.4514 & 0.738 & 0.523 & $-7.7790 * * *$ & 1043 \\
\hline Volt & -0.0999 & 2.3084 & -1.5098 & 7.6785 & $1347.47^{* * *}$ & 5552.38 & 0.113 & 0.105 & $-14.7799 * * *$ & 1043 \\
\hline SENT & -0.00065 & 1.549787 & -0.75393 & 3.716603 & $121.1249 * * *$ & 2502.716 & 0.759 & 0.639 & $-6.5144 * * *$ & 1043 \\
\hline $\mathbf{h}_{\text {op }}$ & -0.09800 & 0.37737 & 0.63245 & 3.05450 & $69.5944 * * *$ & 148.245 & 0.643 & 0.349 & $-15.1497 * * *$ & 1042 \\
\hline $\mathbf{h}_{\mathrm{cl}}$ & -0.09747 & 0.40016 & 0.30020 & 2.71250 & $19.2396 * * *$ & 166.69 & 0.621 & 0.325 & $-15.4865 * * *$ & 1042 \\
\hline
\end{tabular}




\section{Table 2: Estimates of state-space models for herding in the UK mutual funds}

A report of the results of regressions of the following general form:

Model 1: $\log \left[\operatorname{Std}_{\mathrm{c}}\left(\beta_{\mathrm{mt}}^{\mathrm{b}}\right)\right]=\mu_{\mathrm{m}}+\mathrm{H}_{\mathrm{mt}}+\mathrm{v}_{\mathrm{mt}}$ and $\mathrm{H}_{\mathrm{mt}}=\emptyset_{\mathrm{m}} \mathrm{H}_{\mathrm{mt}-1}+\eta_{\mathrm{mt}}$

Model 2: $\log \left[\operatorname{Std}_{\mathrm{c}}\left(\beta_{\mathrm{mt}}^{\mathrm{b}}\right)\right]=\mu_{\mathrm{m}}+\mathrm{H}_{\mathrm{mt}}+\theta_{\mathrm{m} 1} \log \sigma_{\mathrm{mt}}+\theta_{\mathrm{m} 2} \mathrm{R}_{\mathrm{mt}}+\theta_{\mathrm{m} 3} \mathrm{R}_{\mathrm{mt}}^{\mathrm{F}}+\theta_{\mathrm{m} 4} \mathrm{TS}_{\mathrm{t}}+\theta_{\mathrm{m} 5} \mathrm{RTB}_{\mathrm{t}}+v_{\mathrm{mt}} \quad$ and $\mathrm{H}_{\mathrm{mt}}=\emptyset_{\mathrm{m}} \mathrm{H}_{\mathrm{mt}-1}+\eta_{\mathrm{mt}}$ whereStd ${ }_{c}\left(\beta_{\mathrm{imt}}^{\mathrm{b}}\right)$ represent the standard deviation of UK fund betas, $\mathrm{H}_{\mathrm{mt}}$ is the unobservable herding parameter; $\log \sigma_{\mathrm{mt}}$ is log-market-volatility, $\mathrm{R}_{\mathrm{mt}}$ is market return and $\mathrm{R}_{\mathrm{mt}}^{\mathrm{F}}$ is foreign market return at time $t$; $\mathrm{TS}_{\mathrm{t}}$ is the term spread at time $t$. It is the difference between the UK 3-month Treasury Bill rate and the UK 10-year Government Bond rate. RTB is the relative treasury bill rate. It is the difference between the UK 3-month Treasury Bill rate and its 4-week moving average for weekly interval. The sample period is January 1996 - December 2015. Standard Deviations are given in parentheses.

***Statistical significance at $1 \%$ level; **Statistical significance at $5 \%$ level; *Statistical significance at $10 \%$ level.

\begin{tabular}{|c|c|c|c|c|}
\hline \multirow{3}{*}{ Coefficients } & \multicolumn{2}{|c|}{ Open-ended Funds } & \multicolumn{2}{|c|}{ Closed-end funds } \\
\hline & Cross-se & of betas & Cross-se & of betas \\
\hline & Model 1 & Model 2 & Model 1 & Model 2 \\
\hline$\mu_{m}$ & $\begin{array}{c}2.4077^{* * *} \\
(0.0502)\end{array}$ & $\begin{array}{c}2.4234^{* * *} \\
(0.0522)\end{array}$ & $\begin{array}{c}1.8792 * * * \\
(0.0469)\end{array}$ & $\begin{array}{c}1.8936^{* * *} \\
(0.0504)\end{array}$ \\
\hline$\phi_{m}$ & $\begin{array}{c}0.5853 * * * \\
(0.0494)\end{array}$ & $\begin{array}{c}0.5792^{* * *} \\
(0.0273)\end{array}$ & $\begin{array}{c}0.5497 * * * \\
(0.0536)\end{array}$ & $\begin{array}{c}0.5545^{* * *} \\
(0.0272)\end{array}$ \\
\hline$\theta_{m l}$ & & $\begin{array}{l}-0.0053 \\
(0.0090)\end{array}$ & & $\begin{array}{l}-0.0160 * \\
(0.0091)\end{array}$ \\
\hline$\theta_{m 2}$ & & $\begin{array}{c}-0.1064 * * * \\
(0.0133)\end{array}$ & & $\begin{array}{r}-0.1075^{* * *} \\
(0.0139)\end{array}$ \\
\hline$\theta_{m 3}$ & & $\begin{array}{c}-0.0011 \\
(0.0127)\end{array}$ & & $\begin{array}{l}-0.0014 \\
(0.0131)\end{array}$ \\
\hline$\theta_{m 4}$ & & $\begin{array}{c}0.0661 \\
(0.1593)\end{array}$ & & $\begin{array}{c}-0.1252 \\
(0.1644)\end{array}$ \\
\hline$\theta_{m 5}$ & & $\begin{array}{c}1.2094 * * * \\
(0.4614)\end{array}$ & & $\begin{array}{c}1.0505^{* *} \\
(0.4560)\end{array}$ \\
\hline$\sigma_{m v}^{2}$ & $\begin{array}{c}0.1005^{* *} \\
(0.0518)\end{array}$ & & $\begin{array}{c}0.1203^{* *} \\
(0.0579)\end{array}$ & \\
\hline$\sigma_{m \eta}^{2}$ & $\begin{array}{c}0.4360 * * * \\
(0.0696)\end{array}$ & $\begin{array}{c}0.5009 * * * \\
(0.0219)\end{array}$ & $\begin{array}{c}0.4408 * * * \\
(0.0752)\end{array}$ & $\begin{array}{c}0.5236^{* * *} \\
(0.0230)\end{array}$ \\
\hline
\end{tabular}


Table 3: Results of mutual funds herding on UK investor sentiment

Reports the results are regression results of the following general form:

$$
Y_{t}=\Delta+\sum_{i=1}^{p} \Theta_{i} Y_{t-i}+\varepsilon_{t}
$$

where $\mathrm{Y}_{\mathrm{t}}=h_{\mathrm{t}}, \mathrm{R}_{\mathrm{m}, \mathrm{t}}, \mathrm{SENT}_{\mathrm{t}} ; h_{t}$ is the level of investor's herding behaviour at time $t ; h=h_{o p}$, or $h_{c l} ; \boldsymbol{h}_{o p}$ is the herding measure generated by Hwang and Salmon (2004) approach from UK open-ended funds; $h_{c l}$ is the herding measure generated by Hwang and Salmon (2004) approach from UK closed-end funds. $R_{m}$ is the market return; SENT is the constructed UK market investor sentiment index. The data are weekly and cover the period 1st January 1996 to 30th December 2015. The examination of Schwarz information criterion (SC), and Hannan-Quinn information criterion (HQ) suggests the lag order of 2.

$* * *$ Statistical significance at $1 \%$ level; **Statistical significance at $5 \%$ level; *Statistical significance at $10 \%$ level.

\begin{tabular}{|c|c|c|c|c|c|c|}
\hline \multicolumn{7}{|c|}{ Panel A: VAR estimation results } \\
\hline \multirow{2}{*}{$\begin{array}{c}\text { Depend } \\
\text { Variables }\end{array}$} & Lag & \multicolumn{4}{|c|}{ Independ Variables } & \multirow[t]{2}{*}{ Adj $\mathbf{R}^{2}$} \\
\hline & & SENT & $\boldsymbol{R}_{\boldsymbol{m}}$ & $\boldsymbol{h}_{\mathrm{op}}$ & $\boldsymbol{h}_{\mathrm{cl}}$ & \\
\hline \multirow[t]{2}{*}{$\boldsymbol{h}_{\text {op }}$} & 1 & $-0.1047 * * *$ & $-0.0501 * * *$ & $0.4777^{* * *}$ & $0.0932 * *$ & \multirow[b]{2}{*}{0.6420} \\
\hline & 2 & $0.0648 * * *$ & $-0.0311 * * *$ & -0.0288 & -0.0301 & \\
\hline \multirow[t]{2}{*}{$\boldsymbol{h}_{c l}$} & 1 & $-0.1151 * * *$ & $-0.0542 * * *$ & 0.0453 & $0.5063 * * *$ & \multirow[b]{2}{*}{0.6450} \\
\hline & 2 & $0.0900 * * *$ & $-0.0389 * * *$ & 0.0017 & -0.0214 & \\
\hline \multirow[t]{2}{*}{ SENT } & 1 & $0.5922 * * *$ & $0.3215^{* * *}$ & -0.0945 & 0.0935 & \multirow[b]{2}{*}{0.7667} \\
\hline & 2 & $0.1982 * * *$ & $0.0539 * *$ & 0.0076 & -0.1089 & \\
\hline \multirow[t]{2}{*}{$\boldsymbol{R}_{\boldsymbol{m}}$} & 1 & -0.0781 & $-0.057^{* *}$ & -0.3400 & -0.1066 & \multirow[b]{2}{*}{0.0014} \\
\hline & 2 & 0.0051 & -0.0052 & 0.0946 & 0.2699 & \\
\hline
\end{tabular}

\begin{tabular}{|c|c|c|c|c|}
\hline \multicolumn{5}{|c|}{ Panel B: VAR Granger Causality/Block Exogeneity Wald Tests } \\
\hline $\begin{array}{l}\text { Depend } \\
\text { Variahles }\end{array}$ & \multicolumn{4}{|c|}{ Excluded Variables } \\
\hline & $\mathbf{h}_{\mathrm{op}}$ & $\mathbf{h}_{\mathrm{cl}}$ & SENT & $\boldsymbol{R}_{m}$ \\
\hline $\mathbf{h}_{\text {op }}$ & - & $8.2870 * *$ & $134.2514 * * *$ & $247.1328^{* * *}$ \\
\hline $\mathbf{h}_{\mathrm{cl}}$ & 1.6747 & - & $140.6326 * * *$ & $273.0588^{* * *}$ \\
\hline SENT & 0.7159 & 1.2418 & - & $803.8665 * * *$ \\
\hline $\boldsymbol{R}_{m}$ & 1.1055 & 0.8474 & 2.2198 & - \\
\hline
\end{tabular}


Figure 1: Responses to an increase in investor sentiment

Response to Cholesky One S.D. (d.f. adjusted) Innovations \pm 2 S.E.

Response of HCL to UKSENT

(a)

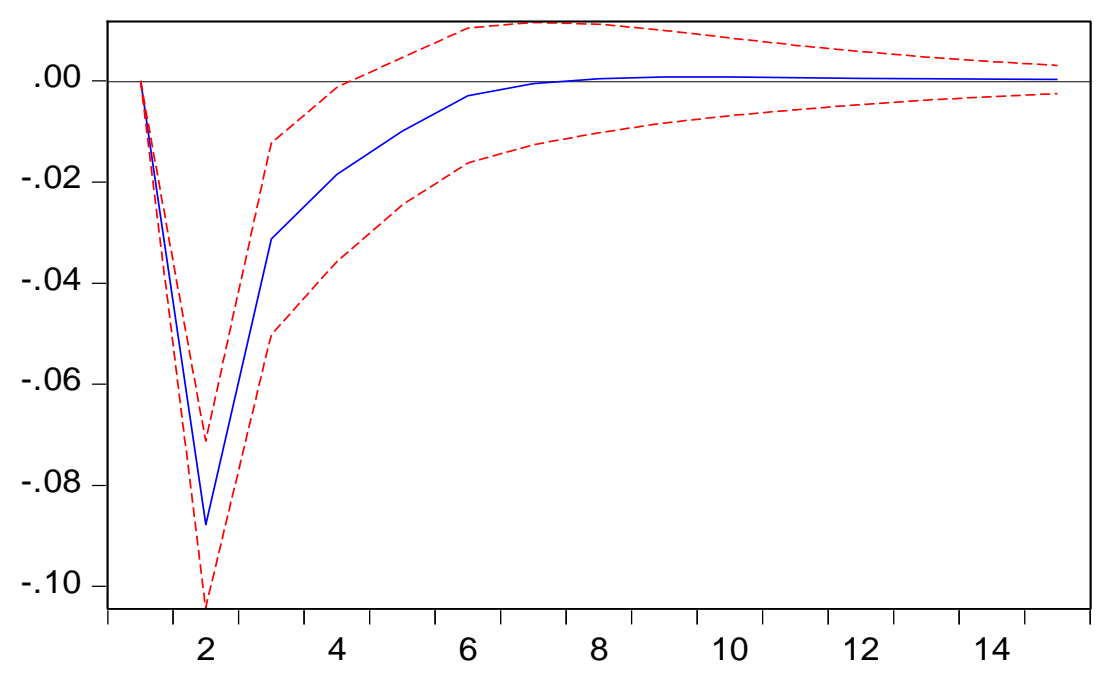

Response of HOP to UKSENT

(b)

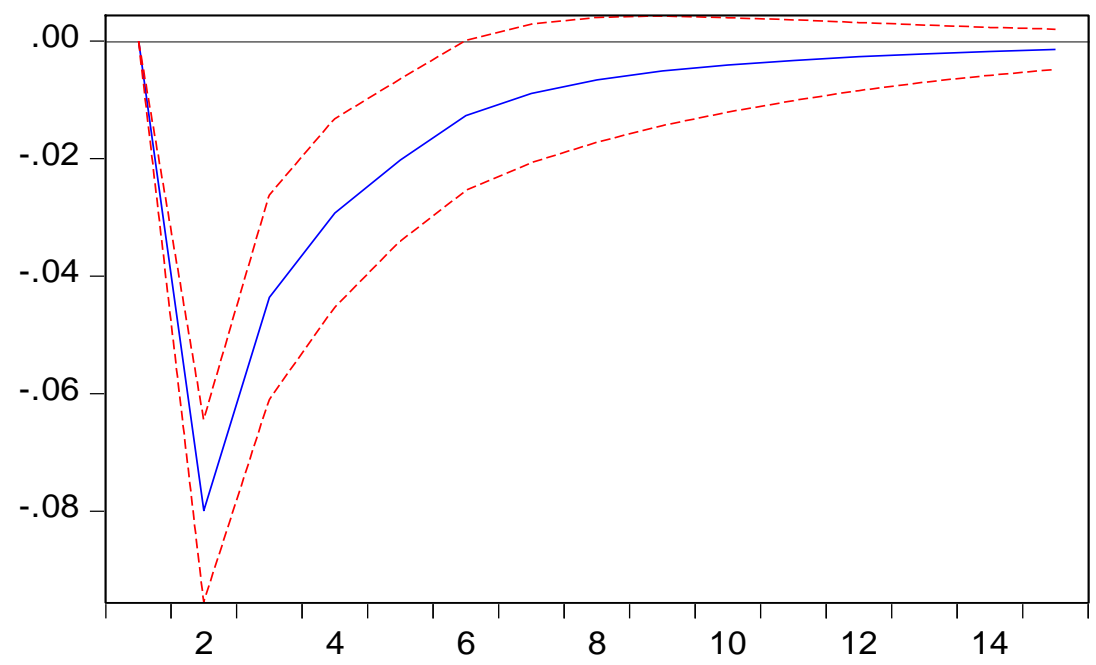




\section{Appendix 1: Construction of the UK Sentiment Indices}

Variables that are used as proxies for sentiment to construct the UK sentiment measures are: the Advances to Declines ratio (AVDC), the Closed-end Fund Discount (CFED), the Money Flow Index (MFI), the Put-call Trading Volume ratio (PCV), the Put-call Open Interest ratio (PCO), which has been argued to be superior to PCV; the Relative Strength Index (RSI), Realized Volatility (VOLA), and Trading Volume (VRA). They are calculated as follow:

\section{Advances-Declines Ratio (AVDC):}

The number of stocks rising in the market

The number of stocks falling in the market

Closed-End Fund Discount (CEFD): CEFD is calculating the value-weighted index of discounts (VWD):

$$
V W D_{t}=\sum_{i=1}^{n_{t}} W_{i} D I S C_{i t}
$$

where: $W_{i}=\frac{N A V_{i t}}{\sum_{i=1}^{n_{t}} N A V_{i t}}, \quad N A V_{i t}=$ net asset value of fund $i$ at end of period $t ; D I S C_{i t}=$ $\frac{N A V_{i t}-S P_{i}}{N A V_{i t}} \times 100, S P_{i}=$ stock price of fund $i$ at end of period $t ; n_{t}$ is the number of funds with available $D I S C_{i, t}$ and $N A V_{i, t}$ data at the end of period t.

Money Flow Index (MFI): Constructing the MFI firstly defines the "typical price" (TP) as:

$$
T P_{t}=\frac{P_{t}^{h}+P_{t}^{l}+P_{t}^{c}}{3}
$$

where, $P_{t}^{h}$ is the highest price at $\mathrm{t}, P_{t}^{l}$ is the lowest price, and $P_{t}^{c}$ is the closing price.

The money flow is then defined as: Typical Price $\times$ Turnover. Positive money flow is when $T P_{t}>T P_{t-1}$. The total money flow over the previous $N$ periods $(N=5$ in this study) is calculated as: 


$$
M F I_{t}=100 \times \frac{\text { Positive Money Flow } t}{\text { Positive Money Flow }_{t}+\text { Negative Money Flow }_{t}}
$$

Put-Call Volume ratio (PCV):

$$
P C V=\frac{\text { volume }_{\text {put }}}{\text { volume }_{\text {call }}}
$$

\section{Put-Call Open interest ratio (PCO):}

$$
P C O=\frac{\text { Open }_{\text {interest }} \text { put }}{\text { Open Interest }}
$$

\section{Relative Strength Index (RSI):}

$$
R S I_{t}=100 \times \frac{\sum_{i=1}^{n}\left(P_{t-1}-P_{t-i-1}\right)_{+}}{\sum_{i=1}^{n}\left|P_{t-1}-P_{t-i-1}\right|}
$$

where $P_{t}$ is the price at time $t ;\left(P_{t-1}-P_{t-i-1}\right)_{+}=P_{t-1}-P_{t-i-1}$ if $P_{t-1}-P_{t-i-1}>0$, otherwise $\left(P_{t-1}-P_{t-i-1}\right)_{+}=0$. We use $\mathrm{n}=14$ as this is one of the most commonly-used indicators in the market.

Realized Volatility (VOLA): The daily high and low of the FTSE100 index future prices is used to compute the weekly realised volatility. It measures investor expectations for market volatility as implied by the skew of FTSE 100 index future.

Trading volume (VRA): We follow Baker and Wurgler (2006) and use a measure of the turnover ratio defined as:

$$
V R A_{t}=100 \times \frac{\operatorname{VOLMA5}_{t}}{\operatorname{VOLMA50}_{t}}
$$

where $V O L M A 5_{t}$ is the average turnover for the past 5 periods, and VOLMA50 is the average turnover for the past 50 periods.

The first principal component of underlying sentiment proxies is used as investor sentiment index (Brown and Cliff, 2004; and Baker and Wurgler, 2006). In the first stage, an Index is calculated by extracting the first principal component from 16 variables: the eight proxy variables and their 
one-period lags. In step two, the correlations between Index and the current and lagged values of each of the proxies are computed. Whichever has the higher correlation with the Index in each pair of current and lagged values is used in the final stage. At the last stage, the sentiment index, SENT, is defined as the first principal component of the correlation matrix of the eight variables selected from step two. 


\section{References}

Andreu, L., Gargallo, Pilar, Salvado, M., and Sarto J.L. (2015) Bayesian analysis of herding behaviour: an application to Spanish equity mutual funds, Applied Stochastic Models in Business and Industry, Vol: 31, pp: 745-761.

Bai, Y., (2014) Cross-border sentiment: an empirical analysis on EU stock markets. Applied Financial Economics, Vol. 24 (4), pp: 259-290.

Baker, M., Wurgler, J. (2006) Investor Sentiment and the Cross-Section of Stock Returns The Journal of Finance, Vol. LXI, No. 4, pp 1645-80.

Baker, M., Wurgler, J., Yuan, Y., (2012) Global, local, and contagious investor sentiment Journal of Financial Economics, Vol. 104, pp: 272-287.

Baker, H. K., Nofsinger, J.R., (2002) Psychological Biases of Investors Financial Services Review; Atlanta Vol. 11(2), pp: 97-116.

Barberis, N., and Shleifer, A. (2003) Style Investing Journal of Financial Economics, Vol. 68 (2), pp: 161-199.

Bertrand, Marianne, Schoar, Annette, 2003. Managing with style: the effect of managers on firm policies. Quarterly Journal of Economics, Vol. 118 (4), 1169 - 1208.

Bikhchandani, S., Sharma, S. (2001) Herd Behaviour in Financial Markets IMF Staff Papers, Vol.47, No. 3

Black, A., Fraser, P., and Power, D. (1992) UK unit trust performance 1980-1989: A passive timevarying approach, Journal of Banking and Finance, Vol. 16, pp:1015-1033

Blasco, N., Corredor, P., and Ferreruela, S. (2012) Market sentiment: a key factor of investors' imitative behaviour, Accounting and Finance, Vol. 52 (3), pp: 663-689

Boco, H., Germain, L., Rousseau, F. (2010) When Overconfident Traders Meet Feedback Traders Working paper series, International Conference of the French Finance Association, May 11-13, 2011.

Boyson, N. M. (2010) Implicit incentives and reputational herding by hedge fund managers Journal of Empirical Finance, Vol. 17, pp: 283-299.

Brown, G.W., and Cliff, M.T. (2004) Investor sentiment and the near-term stock market Journal of Empirical Finance, Vol. 11(1), pp: 1-27. 
Caballe, J., and Sakovics, J. (2003) Speculation against an overconfident market Journal of Financial Market, Vol.6, pp: 199-225.

Chang, E. C., Cheng, J. W. and Khorana, A. (2000) An examination of herd behavior in equity markets: an international perspective Journal of Banking and Finance, Vol. 24, pp:1651-1679.

Charness, G. and Gneezy, U. (2010) Portfolio Choice and Risk Attitudes: An Experiment, Economic Inquiry, Vol. 48 (1), pp: 133-146.

Chen, H., Chong, T.T-L. and Duan, X., 2010. A principal-component approach to measuring investor sentiment. Quantitative Finance, 10(4), 339-347.

Chen, H., Chong, T.T.L., She, Y., 2014. A principal component approach to measuring investor sentiment in China. Quantitative Finance, 14 (4), 573-579.

Chevalier, Judith and Ellison, Glenn, (1999), Are Some Mutual Fund Managers Better Than Others? Cross-Sectional Patterns in Behavior and Performance, Journal of Finance, 54, issue 3, p. 875-899.

Choudhry T., (2005) Time-varying beta and the Asian financial crisis: investigating the Malaysian and Taiwanese firms, Pacific-Basin Finance Journal, Vol. 13(1), pp: 93-118.

Choudhry T., Lu L., Peng K. (2010) Time-varying beta and the Asian financial crisis: evidence from the Asian industrial sectors, Japan and the World Economy, Vol. 22(4), pp: 228-234.

Christie, W.G. and Huang, R.D., (1995) Following the Pied Piper: Do Individual Returns Herd around the Market Financial Analysts Journal, July-August, pp: 31-37.

Claudio, R., and Schmukler, S.L., (2012) On the international transmission of shocks: Microevidence from mutual fund portfolios Journal of International Economics, Elsevier, vol. 88(2), pp: 357-374.

DeLong, J.B., Shleifer, A., Summers, S.H., and Waldmann, R.J. (1990) Positive feedback investment strategies and destabilizing rational speculation The Journal of Finance, Vol. 45(2), p379-395.

Dreman, D. (1979) Contrarian Investment Strategy: The Psychology of Stock Market Success Random House, New York 
Economou, F., Hassapis, C., and Philippas, N. (2018) Investors' fear and herding in the stock market, Applied Economics, Vol. 50 (34-35) pp: 3654-3663.

Engle, R., \& Kroner, K. (1995). Multivariate Simultaneous Generalized Arch. Econometric Theory, 11(1), 122-150.

Friedman, B.M. (1984) A Comment: Stock prices and social dynamics Brookings Papers on Economic Activity, Vol. 2, pp. 504-508.

Froot, K.A., Scharfstein, D.S. and Stein, J.C. (1992) Herd on the Street: Informational Inefficiencies in a Market with Short-Term Speculation Journal of Finance, 47, pp: 1451-84.

Graham, John R., 1999. Herding among investment newsletters: theory and evidence. The Journal of Finance, Vol.54 (1), pp:237-268.

Grinblatt, M.S, Timan, S., and Wermers, R. (1995) Momentum investment strategies, portfolio performance and herding: A study of mutual fund behaviour American Economic Review, Vol. 85, pp: 1088-1105.

Hirshleifer, D., Subrahmanyam, A., and Titman, S. (1994) Security analysis and trading patterns when some investors receive information before others Journal of Finance, Vol. 49, pp: 1665-98.

Hudson, Y. and Green, C.J., (2015) Is investor sentiment contagious? International sentiment and UK equity returns, Journal of Behavioral and Experimental Finance, Vol.5, pp: 46-59.

Hwang, S. and Salmon, M. (2004) Market stress and herding Journal of Empirical finance, Vol. 11, pp: 585-616.

Hwang, S. and Salmon, M, (2017) Overconfidence, Sentiment and Beta Herding, working paper.

Khan, H., Hassairi, S.A., \& Viviani, J.L., (2011) Herd Behavior and Market Stress: The Case of Four European Countries, International Business Research, vol. 4(3) pp. 53- 67.

Lakonishok, J., Shleifer, A., \& Vishny, R.W. 1992, The impact of institutional trading on stock prices Journal of Financial Economics, Vol. 32, pp: 23-43.

Lee, C.M.C., Shleifer, A., Thaler, R.H., 1991, Investor Sentiment and the Closed-End Fund Puzzle Journal of Finance, Vol.46, 75-109.

Liao, T.L., Huang, C.J. and Wu, C.Y. (2011) Do Fund Managers Herd to Counter Investor Sentiment? Journal of Business Research, Vol. 64(2), pp: 207-212. 
Li, X. (2002) Performance, Herding, and Career Concerns of Individual Financial Analysts. Vanderbilt University Working paper.

Lux, T. and Marchesi, M. (1999) Scaling and Criticality in a Stochastic Multi-agent Model of a Financial Market, Nature, Vol. 397, pp: 498-500.

Manconi, A., Massa, M., Yasuda, A. (2012) The role of institutional investors in propagating the crisis of 2007-2008 Journal of Financial Economics, Vol.104, pp: 491-518.

Menkhoff, L., Schmidt, U., and Brozynskia, T. (2006) The impact of experience on risk taking, overconfidence, and herding of fund managers: Complementary survey evidence European Economic Review, Vol. 50(7), pp:1753-1766.

Odean, T. (1998) Volume, Volatility, Price, and Profit when all traders are above average Journal of Finance, Vol.53(6), pp: 1887-934.

Olsen, R. A. (2011). Financial risk perceptions: A behavioral perspective. In R. Yazdipour (Ed.), Advances in entrepreneurial finance with applications from behavioral finance and economics (pp. 45-68). New York: Springer

Prechter, R. R. (2001) Unconscious Herding Behavior as the Psychological Basis of Financial Market Trends and Patterns, The Journal of Psychology and Financial Markets, Vol. 2(3), pp: $120-125$.

Pool, V.K., Stoffman, N., and Yonkwer, S.E. (2015) The People in Your Neighborhood: Social Interactions and Mutual Fund Portfolios, The Journal of Finance, Vol. 70(6), pp: 2679-2732.

Scharfstein, D.S. and Stein, J. (1990) Herd behaviour and investment The American Economic Association, Vol. 80(3), p465-479.

Shiller, R. J., Fischer, S., and Friedman, B.M. (1984) Stock Prices and Social Dynamics Brookings Papers on Economic Activity, Vol. 1984(2), pp: 457-98.

Shiller, R. J. (2002) Bubbles, Human Judgment, and Expert Opinion, Financial Analysts Journal, Vol. 58 (3), pp: 18-26.

Shleifer, A. (2000) Inefficient Market Oxford University Press

Sias, R. W. (2004) Institutional Herding, The Review of Financial Studies, Vol. 17(1), pp: 165206. 
Stelios, B., Mouna, J., Brian, L., Kamel, N., and Gazi, S.U. (2017) Herding behaviour, market sentiment and volatility: Will the bubble resume?, The North American Journal of Economics and Finance, Vol 42(1), pp: 107-131.

Tsui AK, Yu Q (1999) Constant conditional correlation in a bivariate GARCH model: evidence from the stock markets of China, Mathematics and Computers in Simulation, Vol.48 (4-6), pp: 503-509.

Wermers, R. (1999) Mutual found herding and the impact on stock price Journal of Finance, Vol. 54(2), pp: 581-622.

Wylie, S. (2005) Fund Manager Herding: A Test of the Accuracy of Empirical Results Using U.K. Data Journal of Busines, Vol.78 (1), pp: 381-403.

Yin, S., Mazouz, K., Benamraoui, A. and Saadouni, B. (2017). Stock price reaction to profit warnings: the role of time-varying betas. Review of Quantitative Finance and Accounting, 50(1), pp.67-93. 